\title{
Engineering n-p junction for photo-electrochemical hydrogen production
}

\author{
J. Toupin ${ }^{a, b, c}$, H. Strub ${ }^{b}$, S. Kressmann ${ }^{b}$, M. Boudot ${ }^{a}$, V. Artero ${ }^{c}$ and Ch. Laberty-Robert ${ }^{a} *$ \\ The generation of hydrogen from water and sunlight offers a promising approach for producing scalable and sustainable \\ carbon free fuels. One of the challenges of solar-to-fuel technology is the design of efficient, long-lasting and low-cost \\ photocathodes, which are responsible for absorbing sunlight and driving catalytic hydrogen evolution. We report on the \\ protection of a $\mathrm{Cu} / \mathrm{Cu}_{2} \mathrm{O} / \mathrm{CuO}$ photoelectrode against photocorrosion by a 200-300 nm-thick $\mathrm{BaTiO}_{3}$ perovskite layer, \\ deposited using the sol-gel method. This photoelectrode mediates $\mathrm{H}_{2}$ production with a current density of $\sim 3.1 \mathrm{~mA} . \mathrm{cm}^{-2}$ \\ at $0 \mathrm{~V}$ versus $\mathrm{RHE}$ under 3 sun irradiation and in $\mathrm{pH}=6$ aqueous electrolyte. While unprotected $\mathrm{Cu} / \mathrm{Cu}{ }_{2} \mathrm{O} / \mathrm{CuO}$ \\ photoelectrodes show a rapid decay of activity, the $\mathrm{BaTiO}_{3}$-protected photoelectrodes exhibit $\sim 10 \%$ current decay over \\ $20 \mathrm{~min}$.
}

\section{A. Introduction}

Concerns over climate change resulting from accumulation of anthropogenic carbon dioxide in the atmosphere and the uncertainty in the amount of recoverable fossil fuels reserves are driving forces for the development of renewable, carbonneutral energy technologies. The production of hydrogen from water and sunlight in photoelectrochemical cells (PECs) is an appealing technology for producing a scalable and sustainable carbon-free fuel. ${ }^{1}$ To design efficient PECs, one of the challenges is the availability of earth-abundant semiconducting photoelectrode materials that absorb sunlight and drive the two water splitting half-reactions ${ }^{2}$.Up to now, a large number of photoelectrode materials, including metal oxides and other chalchogenides or group III$\mathrm{V}$ semiconductors, have been explored. Significant improvements on the solar-to-hydrogen efficiency have been reported ${ }^{3}$ but not a single material has yet been found that simultaneously satisfies both efficiency, cost-effectiveness and stability required to widespread the photoelectrochemical technology. ${ }^{4,5}{ }^{6} \mathrm{Cu}_{2} \mathrm{O}$ is a promising photocathode material due to its suitable band gap (1.9 $2.2 \mathrm{eV}$ ), high absorption coefficient in the visible range $7,8,9,10,11$ and theoretical photocurrent of $14.7 \mathrm{~mA} \cdot \mathrm{cm}^{-2} \cdot 12$ Its conduction band is located cathodic to the reduction potential of water, making it suitable for mediating $\mathrm{H}_{2}$ production in a PEC cell. Among different synthesis methods tested, electrodeposition has been proven to be the most convenient and reliable to prepare nanostructured $\mathrm{Cu}_{2} \mathrm{O}$. ${ }^{13}$, 14, 15, 16, 17 Indeed, $\mathrm{Cu}_{2} \mathrm{O}$ morphology and orientation can be tuned by judiciously setting deposition parameters such as the electrolyte $\mathrm{pH}$, temperature, applied potential and current density. Controlling the morphology and crystal structure of the electrodes allows enhancing their performances that mainly rely on their light absorption and charge transport properties.

Although $\mathrm{Cu}_{2} \mathrm{O}$ possesses an intrinsic potential as a photocathode, the reported photocurrents remain far below the theoretical values. These poor performances arise essentially from structural defects at the semiconductorelectrolyte interface. Indeed, at low applied potentials, $\mathrm{Cu}_{2} \mathrm{O}$ does not transfer electrons efficiently toward the electrolyte due to an inappropriate band bending. Additionally, $\mathrm{Cu}_{2} \mathrm{O}$ suffers from reduction to $\mathrm{Cu}$ under irradiation in aqueous solutions, because of the positioning of the redox potentials of the $\mathrm{Cu}_{2} \mathrm{O} / \mathrm{Cu}$ couple within the band-gap. ${ }^{12,18}$ This latter limits both the efficiency and lifetime of copper-based photocathodes. Extensive efforts have then been directed toward the development of architectures that integrate heterojunctions, catalysts and protective insulating layers, ${ }^{12}$ with the aim at improving the stability and solar-to-hydrogen conversion efficiency. Building heterojunction structures with other semiconductors, such as $\mathrm{CuO} / \mathrm{ZnO},{ }^{19} \mathrm{CuO} / \mathrm{TiO}_{2}{ }^{20}$ $\mathrm{Cu}_{2} \mathrm{O} / \mathrm{TiO}_{2}{ }^{21}$ for efficient separation of photogenerated electron-hole pairs indeed improved the performance of the photoelectrodes and their stability. Among the various heterojunction studied, the $\mathrm{Cu}_{2} \mathrm{O} / \mathrm{CuO}$ heterojunction proved to be particularly promising. $\mathrm{CuO}$ is a p-type oxide for photoelectrochemical hydrogen production with a direct bandgap of $1.3-1.7 \mathrm{eV}$, depending on the preparation methods and conditions. ${ }^{22}, 23,24$ In the $\mathrm{Cu}_{2} \mathrm{O} / \mathrm{CuO}$ heterojunction, the electrons photogenerated in $\mathrm{Cu}_{2} \mathrm{O}$ will flow toward $\mathrm{CuO}$ because the conduction band edge of $\mathrm{CuO}$ is at lower potential than the one of $\mathrm{Cu}_{2} \mathrm{O} .{ }^{25}$ Reported $\mathrm{Cu}_{2} \mathrm{O} / \mathrm{CuO}$ photocathode indeed exhibited photocurrent density for hydrogen evolution of $3.15 \mathrm{~mA} . \mathrm{cm}^{-2}$ at $0.4 \mathrm{~V}$ vs. $\mathrm{RHE}$, which was one of the highest reported at this potential on copper-oxide-based photocathodes. ${ }^{26}$ The high photoactivity of these electrodes was ascribed to i) the broadened light absorption band due to combined absorption by $\mathrm{CuO}$ and $\mathrm{Cu}_{2} \mathrm{O}$ that harvest more solar energy, ii) the large depletion region that enhances electron-hole separation, and iii) the high majority charge carrier density that ensures a faster charge transportation rate.

In this paper, we report on the use of electrodeposition to synthesize $\mathrm{Cu} / \mathrm{Cu}_{2} \mathrm{O} / \mathrm{CuO}$ photoelectrodes and on the amelioration of their stability through the deposition of a thin layer of $n$-type large-bandgap oxide semiconductor. First, the protection of our $\mathrm{Cu} / \mathrm{Cu}_{2} \mathrm{O} / \mathrm{CuO}$ photoelectrodes was performed by the deposition of $\mathrm{TiO}_{2}$ thin layer. This layer induces a decrease of the photo electrochemical activity of our copper based photo-electrodes but with an increase of their stability, demonstrating the interest of such an approach. We then changed our strategy to deposit a thin layer of $\mathrm{BaTiO}_{3}$ by sol-gel chemistry coupled with dip-coating technique. $\mathrm{BaTiO}_{3}$ appears to be an interesting protecting layer as it is also stable in water and can act as a 
tunneling junction for charge transport due to a favorable band alignment.

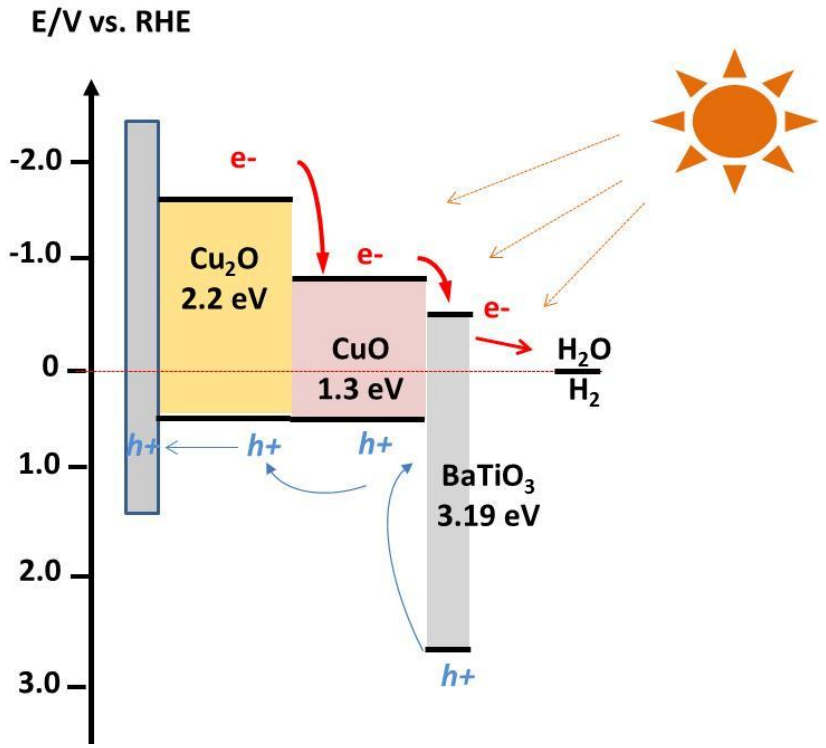

Figure 1. Energy level scheme of the $\mathrm{BaTiO}_{3}-$ protected copper based photocathode at $\mathrm{pH}=0$. At the photocathode, protons are reduced to hydrogen by the photogenerated electrons. The scheme illustrates the generation and transport of the charge carriers, and highlights the minimum conduction-band offset between $\mathrm{BaTiO}_{3}$ and copper oxides, needed for electrons to be transported across the protection layer.

Compared to $\mathrm{TiO}_{2}$, the edge of its conduction band (-0.5 V vs RHE, determined through Mott-Schottky measurement, data not shown ${ }^{27}$ ) is indeed closer to that of $\mathrm{CuO}$, favoring electron transport thanks to a more favorable band alignment and providing more driving force for hydrogen evolution at the electrode surface. These combined effects enhance the photoelectrochemical activity while photocorrosion damages are limited since contact of the aqueous electrolyte with the copper-based photoelectrodes is avoided. The $\mathrm{Cu} / \mathrm{Cu}_{2} \mathrm{O} / \mathrm{CuO} / \mathrm{BaTiO}_{3}$ photocathodes revealed to be quite stable with little degradation observed at $0 \mathrm{~V}$ vs RHE after 20 min of illumination at $\mathrm{pH}=6$ (about $10 \%$ of degradation). A photocurrent of $\sim 3.1 \mathrm{~mA} . \mathrm{cm}^{-2}$ was measured, which rank these architectures among the best copper-based photoelectrodes for hydrogen evolution.

\section{B. Experimental}

\section{Synthetic procedures}

\section{Cu electrodeposition.}

The copper films were deposited by electrodeposition from an acid solution of copper sulphate. The deposition substrate (working electrode) was fluorine-doped tin oxide (FTO, Asahi 80 Solems). The FTO substrates were first conditioned during 10-20 s under cathodic current $\left(-25 \mathrm{~mA} / \mathrm{cm}^{2}\right)$ in a solution made of $0.01 \mathrm{M}$ of $\mathrm{Na}_{2} \mathrm{SO}_{4} \cdot 10 \mathrm{H}_{2} \mathrm{O}$ and $0.1 \mathrm{M}$ of $\mathrm{H}_{2} \mathrm{SO}_{4}$. This pre-treatment was necessary to achieve better substrate adhesion of the electrodes and reproducibility. ${ }^{21}$ The plating bath was $0.8 \mathrm{M} \mathrm{Cu}\left(\mathrm{SO}_{4}\right)$ and $0.45 \mathrm{M} \mathrm{H}_{2} \mathrm{SO}_{4}$ in deionized water at ambient temperature. The $\mathrm{Cu}$ films were deposited at a constant current density (- $220 \mathrm{~mA} / \mathrm{cm}^{2}$, galvanostatic mode) using a biologic potentiostat in a three-electrode configuration (a copper electrode served as the counter electrode and $\mathrm{Ag} / \mathrm{AgCl}$ served as reference electrode), which resulted in a film of several $\mu \mathrm{m}$ thickness. During this step, because of the current applied, the formation of $\mathrm{H}_{2}$ occurs. Lately, these $\mathrm{H}_{2}$ bubbles bounded at the surface are covered by copper and the resulting film is made of empty spheres bounded to each other. This morphology is kept after the anodization step, during which $\mathrm{Cu}$ is transformed into $\mathrm{Cu}(\mathrm{OH})_{2}$ and $\mathrm{CuO}$, the heat treatment and the deposition of $\mathrm{BaTiO}_{3}$.

Anodization. The anodization solution consisted of aqueous $\mathrm{NaOH}(1 \mathrm{M})$ and anodization was performed at $3 \mathrm{~mA} / \mathrm{cm}^{2}$ in a three-electrode configuration.

CuO formation. Heat treatment was finally achieved at $450^{\circ} \mathrm{C}$ in the air for 30 to transform $\mathrm{Cu}(\mathrm{OH})_{2}$ into $\mathrm{CuO}$.

$\mathrm{TiO}_{2}$ deposition. $\mathrm{TiO}_{2}$ was deposited using the sol-gel and dip-coating methods. First, a Ti5E solution was prepared by mixing $19 \mathrm{~g}$ of $\mathrm{TiCl}_{4}$ and $23 \mathrm{~g}$ of absolute ethanol. This solution is then mixed with $5.7 \mathrm{~g}$ of absolute ethanol and deposited onto the $\mathrm{FTO} / \mathrm{Cu} / \mathrm{Cu}_{2} \mathrm{O} / \mathrm{CuO}$ substrate with a withdrawal speed of $2.5 \mathrm{~mm} / \mathrm{s}$. A heat treatment at $400^{\circ} \mathrm{C}$ for $1 \mathrm{~min}$ under air is applied between each layer and the final treatment is $500^{\circ} \mathrm{C}$ for $1 \mathrm{~h}$ in air.

$\mathrm{BaTiO}_{3}$ deposition. $\mathrm{BaTiO}_{3}$ was deposited using the sol-gel and dip-coating methods. The sol-gel solution is made of $1.42 \mathrm{~g} \mathrm{Ba}(\mathrm{OH})_{2} .7 \mathrm{H}_{2} \mathrm{O}$ (Sigma Aldrich) and $1.36 \mathrm{~g}$ of titanium isopropoxide (sigma Aldrich) in acetylacetone $(0.36 \mathrm{~g})$, glacial acetic acid (6g) and ethanol (9g). Pluronic ${ }^{\oplus}$ F127 (0.28 g) was added to the previous solution to obtain homogenous film. The FTO/Cu/Cu2O/CuO substrate was dipped into the sol-gel solution and then removed at $2.5 \mathrm{~mm} / \mathrm{s}$; to increase the thickness of the $\mathrm{BaTiO}_{3}$ film, several layers (two layers) have been deposited. In that case, the films were placed for 60 $\min$ in a furnace preheated at $350^{\circ} \mathrm{C}$ before a new layer is deposited. Final heat-treatment in the air at $600^{\circ} \mathrm{C}$ for 15 min was applied.

Structural characterization. The morphology of the films was characterized using a high-resolution scanning electron microscope (Hitachi SU70). XRD patterns were acquired with a Bruker D8 Discover diffractometer in the Bragg-Brentano mode, using $\mathrm{Cu} \mathrm{K} \alpha$ radiation (1.540598 $\AA$ ) and a $\mathrm{Ni} \beta$-filter. Spectra were acquired with a 1D Lynxeye detector from $2 \theta=$ $20^{\circ}-80^{\circ}$ at a step width of $0.05^{\circ}$ with acquisition time of $1 \mathrm{~s}$ and a source slit width of $4 \mathrm{~mm}$.

Photoelectrochemical measurements. The photoelectroche mical performances of the electrodes were evaluated in a three-electrode configuration under front-side light illumination using a Solartron Ametek 2087A Potentiostat / Galvanostat / impedancemeter. The electrolyte was a $1.0 \mathrm{M} \mathrm{Na} \mathrm{SO}_{4}$ solution buffered at $\mathrm{pH} 6$ with potassium phosphate $(0.1 \mathrm{M})$. The reference electrode was $\mathrm{Ag} / \mathrm{AgCl}$ in saturated $\mathrm{KCl}$, and a Pt wire was used as the counter electrode. The photoresponse was measured under chopped irradiation from a $280 \mathrm{~W}$ Xe lamp equipped with an ultraviolet filter (Oriel 51272, 400nm) and IR radiation $(\lambda>$ $950 \mathrm{~nm}$ ) filter. The light intensity was measured with 1918-R Newport power meter 918D-UVOD3R,UV Silicon Detector 
$(200-1100 \mathrm{~nm})$ and estimated to 3 suns $\left(240 \mathrm{~mW} \cdot \mathrm{cm}^{-2}\right.$, visible-IR irradiation). ${ }^{28}$ The scan rate for the linear sweep voltammetry measurements was $20 \mathrm{mV} \mathrm{s}^{-1}$. Impedance spectroscopy measurements have been performed using the following parameters: frequency range $(200 \mathrm{kHz}-0.1 \mathrm{~Hz})$ at $0 \mathrm{~V}$ vs. $\mathrm{RHE}$ at $\mathrm{pH}=6$. The $\Delta \mathrm{E}$ is $20 \mathrm{mV}$. Mott-Schottky diagrams were obtained from measurements performed in $\mathrm{pH} 14 \mathrm{NaOH}$ electrolyte. The potential varied between $-1.5 \mathrm{~V}$ and $2.6 \mathrm{~V}$ vs. RHE and the measurement was performed at $1 \mathrm{kHz}$. Photocurrent stability tests were carried out by measuring the photocurrent produced under chopped light irradiation $(0.1 \mathrm{~Hz}$ light/dark cycles frequency) at a fixed potential of $0 \mathrm{~V}$ versus RHE. During linear sweep voltammetry (j-V plots) and chronoamperometry (stability plots) the electrolyte was continuously bubbled with $\mathrm{N}_{2}$ to remove oxygen and thus eliminate erroneous signals arising from oxygen reduction.

Stability and faradic measurements were tested in a laboratory fabricated air tight $\mathrm{H}$-cell with a plastic window allowing a 3-electrode setup, with the reference and counter electrodes separated by glass frits from the main compartment. Hydrogen in the headspace of the cell was detected with a Perkin Elmer Clarus 580 gas chromatograph equipped with a TCD and nitrogen carrier gas operating at $32^{\circ} \mathrm{C}$. For $\mathrm{H}_{2}$ detection, the electrochemical cell used was gas tight and no mixture between gas formed at the working electrode and the counter electrode was possible.

UV-visible absorption spectra were measured using an Agilent Technologies Cary Series spectrophotometer.

\section{Results and Discussion}

\section{Synthesis and characterization of $\mathrm{Cu} / \mathrm{Cu}_{2} \mathrm{O} / \mathrm{CuO}$} photoelectrodes.

The $\mathrm{Cu} / \mathrm{Cu}_{2} \mathrm{O} / \mathrm{CuO}$ photoelectrodes used in this study were prepared by electrodeposition of copper metal followed by an anodization process and a calcination step at $450^{\circ} \mathrm{C}$ in the air. The details of the procedure are described in the experimental section. The currents applied during the cathodic electrodeposition and anodization steps were chosen at $-20 \mathrm{~mA} . \mathrm{cm}^{-2}$ and $+3 \mathrm{~mA} . \mathrm{cm}^{-2}$, respectively. For the sake of simplicity, the $\mathrm{Cu} / \mathrm{Cu}_{2} \mathrm{O} / \mathrm{CuO}$ photoelectrodes were named EA $X-Y$ where $X$ is the duration of electrodeposition and $Y$ is the duration of anodization ( $X$ and $Y$ are expressed in min.). Anodization simultaneously produces $\mathrm{Cu}_{2} \mathrm{O}$ and $\mathrm{Cu}(\mathrm{OH})_{2}$. The films are blue which is characteristic of the presence of $\mathrm{Cu}(\mathrm{OH})_{2}$. Calcination at $450^{\circ} \mathrm{C}$ in the air was then performed to transform $\mathrm{Cu}(\mathrm{OH})_{2}$ into $\mathrm{CuO}$. During this step, the colour of the films evolves from blue to dark grey/black.

XRD patterns obtained for photoelectrodes with different anodization and electrodeposited times are reported in Figure 2.1.
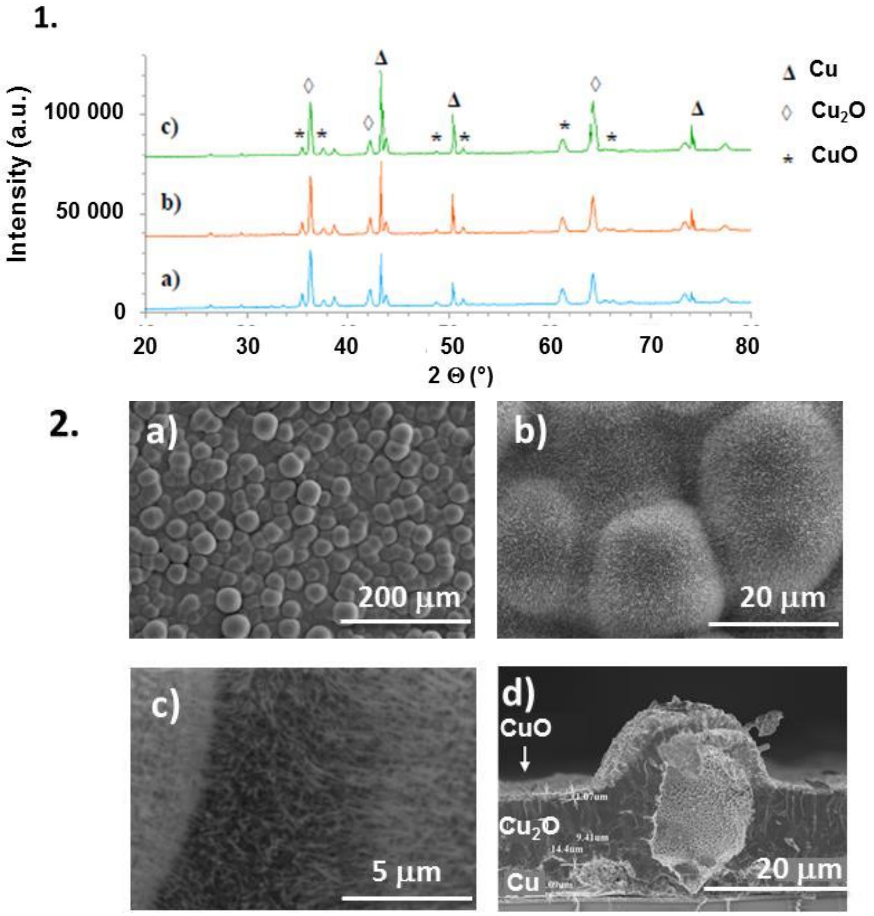

3.
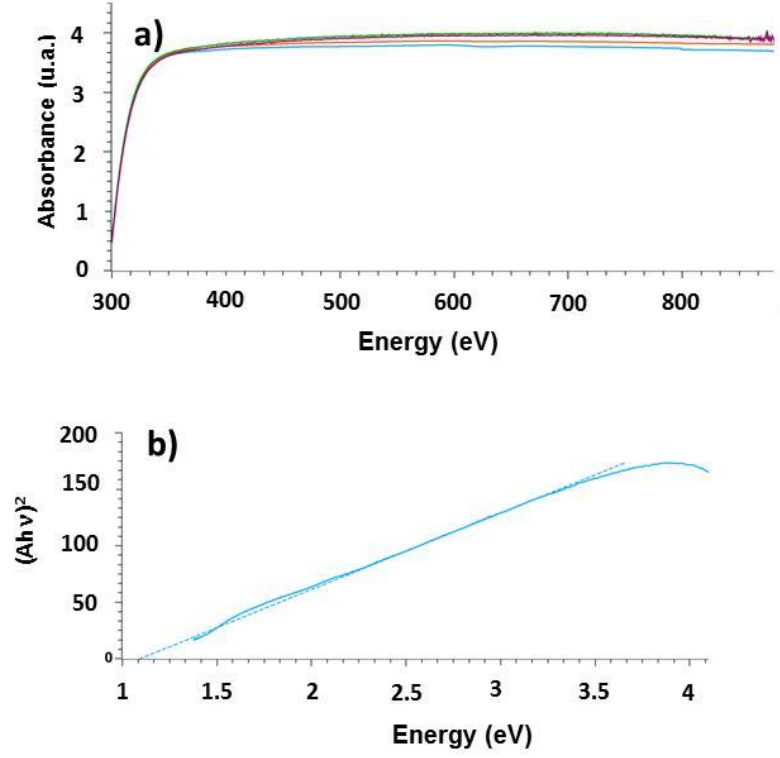

Figure 2. X-rays diffraction patterns, particle morphology and optical property of $\mathrm{Cu} / \mathrm{Cu}_{2} \mathrm{O} / \mathrm{CuO}$ films. 1) X-rays diffraction patterns of EA 5-5 (a), EA 10-5 (b) and EA 15-5 (c) photoelectrodes; 2) SEM images of EA 20-20 photoelectrodes (a-c) and cross-section image for EA 5-10 photoelectrode (d); 3) UV-visible absorbance (a) for EA 5-15 (blue), EA 10-15 (orange), EA 15-15 (green) and EA 10-20 (purple) photoelectrodes and TAUC plot (b) for EA 15-15. 
Table 1. $\mathrm{Cu}, \mathrm{Cu}_{2} \mathrm{O}$ and $\mathrm{CuO}$ crystallite size (in $\mathrm{nm}$ with error of $\pm 10 \mathrm{~nm}$ ) for photoelectrodes synthesized under various conditions.

\begin{tabular}{cccccc}
\hline Compounds & EA & EA & EA & EA & EA \\
& $5-5$ & $5-10$ & $10-5$ & $10-15$ & $15-5$ \\
\hline $\mathrm{Cu}$ & 113 & 115 & 103 & 120 & 106 \\
\hline $\mathrm{Cu}_{2} \mathrm{O}$ & 24 & 25 & 26 & 22 & 24 \\
\hline $\mathrm{CuO}$ & 20 & 35 & 29 & 28 & 20 \\
\hline
\end{tabular}

These XRD patterns confirm the coexistence of $\mathrm{Cu}, \mathrm{Cu}_{2} \mathrm{O}$ and $\mathrm{CuO}$. We notice that the intensity of peaks relative to copper increases with the electrodeposition time while the ratio between the intensity of peaks corresponding to copper oxides $\left(\mathrm{Cu}_{2} \mathrm{O}\right.$ and $\left.\mathrm{CuO}\right)$ augments with the anodization time. Furthermore, the electrodeposited copper layer exhibits preferential (111) and (200) orientations, 29, 30,31 which impacts the growth direction of $\mathrm{Cu}_{2} \mathrm{O}$ oxides. Indeed, $\mathrm{Cu}_{2} \mathrm{O}$ oxide exhibits a preferential (111) orientation, which has been shown to have a low resistivity with a concentration of charge almost twice as high as (100) orientation. ${ }^{32}$ The crystallite size was estimated from XRD patterns using Debye-Scherrer formula and estimated to $\sim 100 \mathrm{~nm}$ for $\mathrm{Cu}$, $\sim 24 \mathrm{~nm}$ for $\mathrm{Cu}_{2} \mathrm{O}$ and $\sim 31 \mathrm{~nm}$ for $\mathrm{CuO}$. The electrodeposited and anodization times do not influence the particle size as shown in Table 1.

Scanning electron microscopy (SEM) images (Figure 2.2) indicate that the surface of the electrode is a continuous layer embedding spheres with several $\mu \mathrm{m}$ diameters. Cross section images show that the core of the sphere is empty, which is likely due to the formation of $\mathrm{H}_{2}$ bubbles during copper electrodeposition. Furthermore, these spheres exhibit thin needles at their surface. Cross-section analyses indicated that the film was composed of three layers: metallic copper, $\mathrm{Cu}_{2} \mathrm{O}$ and $\mathrm{CuO}$. The same layers were noticed within the shell of the spheres as well. The dependence of the thickness of the three layers on the current density used during synthesis was studied by analysing cross-section SEM images. It appeared that the thicknesses of $\mathrm{CuO}(1 \mu \mathrm{m})$ layer remain the same whatever the electrodeposition and the anodization time. The thickness of the $\mathrm{Cu}$ layer linearly depends on the time of electrodeposition. Increasing the anodization time leads to thicker $\mathrm{Cu}_{2} \mathrm{O}$ film. The combined thickness of these three different layers was estimated to $\sim 20 \mu \mathrm{m}$ for EA $20-20$ photoelectrodes. The needles' formation was assigned to the oxidation reaction at the $\mathrm{Cu}_{2} \mathrm{O} / \mathrm{CuO}$ interface that induces a compressive stress in the $\mathrm{CuO}$ layer favouring the diffusion of copper along the $\mathrm{CuO}$ grain boundaries. ${ }^{32,33}$ The $\mathrm{CuO}$ film then acts as a substrate for the growth of $\mathrm{CuO}$ needles. This mechanism starts when the CuO layer is about $1 \mu \mathrm{m}$ thick and leads to $\mathrm{CuO}$ needles which are several $\mu \mathrm{m}$ long.

The ultraviolet-visible (UV) diffuse reflectance spectrum (figure 2.3) indicated that the dark $\mathrm{Cu} / \mathrm{Cu}_{2} \mathrm{O} / \mathrm{Cu}$ films absorb solar energy for wavelengths higher than $350 \mathrm{~nm}$ whatever the experimental conditions used for their synthesis. Further analysis of the absorption spectrum revealed a direct bandgap of $1.1 \mathrm{eV}$. This latter is slightly lower than the values reported for $\mathrm{CuO}$ (1.3-1.9 eV).

Linear sweep voltammetry in the dark and under chopped-light irradiation conditions was used to investigate the effect of the experimental conditions used for the synthesis of the photoelectrodes on the current density at $\mathrm{pH}=6$ (Figure 3 and Table 2).

Table 2. Current density measured at $0 \mathrm{~V}$ vs. RHE from $I-V$ curves and $\mathrm{pH}=6$ under 3 sun visible-light irradiation for copper-based photoelectrodes produced with different synthesis conditions.

\begin{tabular}{c|c|c|c}
\hline Electrode & EA15-15 & EA20-20 & EA30-30 \\
\hline $\begin{array}{c}\text { Current } \\
\text { density } \\
\left(\mathrm{mA} . \mathrm{cm}^{-2}\right)\end{array}$ & -2.7 & -4.3 & -3.2 \\
\hline
\end{tabular}

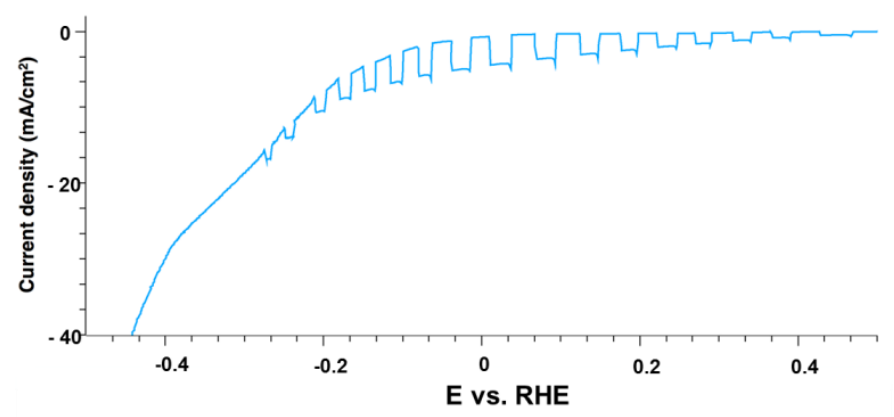

Figure 3. Current density versus potential curves for the EA 20-20 Cu/ $\mathrm{Cu}_{2} \mathrm{O} / \mathrm{CuO}$ electrode at $\mathrm{pH}=6$ under a 3 sun visible-light chopped irradiation.

Cathodic photocurrents confirm that these films behave as p-type semi-conductor. The onset photocurrent potential is $\sim 0.4 \mathrm{~V}$ versus RHE indicating that these electrodes can be practically used as photocathodes in the context of photoelectrochemical water-splitting.

Table 2 summarizes photo-electrochemical performances of $\mathrm{Cu} / \mathrm{Cu}_{2} \mathrm{O} / \mathrm{CuO}$ electrodes synthesized with different anodization and electrodeposition times. High photocurrents values ranging between $-2.7 \mathrm{~mA} . \mathrm{cm}^{-2}$ and $-4.3 \mathrm{~mA} . \mathrm{cm}^{-2}$ are obtained at $0 \mathrm{~V}$ vs. RHE and $\mathrm{pH}=6$. The best result are obtained for anodization and electrodeposition times of 20 min. Increasing those times, and therefore the thickness of the $\mathrm{Cu}_{2} \mathrm{O}$ layer, did not improve photocurrent values above $-4.3 \mathrm{~mA} \cdot \mathrm{cm}^{-2}$ at OV vs RHE, $\mathrm{pH}=6$. Indeed, the depth of penetration of light in the electrode can be estimated between $4 \mu \mathrm{m}$ and $10 \mu \mathrm{m}$, depending on the synthesis parameters, from the absorbance study and the electrode thickness. Whatever the experimental synthetic conditions used, these values are lower than the thickness of both $\mathrm{CuO}$ and $\mathrm{Cu}_{2} \mathrm{O}$ layers $(>15 \mu \mathrm{m})$, indicating that the maximum photocurrent measured correspond to optimal light harvesting by the photoelectrode. 
Stability measurements were conducted using chronoamperometry measurements at $0 \mathrm{~V}$ vs. RHE. As shown in Figure 4, degradation readily occurs after $20 \mathrm{~min}$ of operation, which suggests photocorrosion of $\mathrm{CuO}$ and $\mathrm{Cu}_{2} \mathrm{O}$ layers.

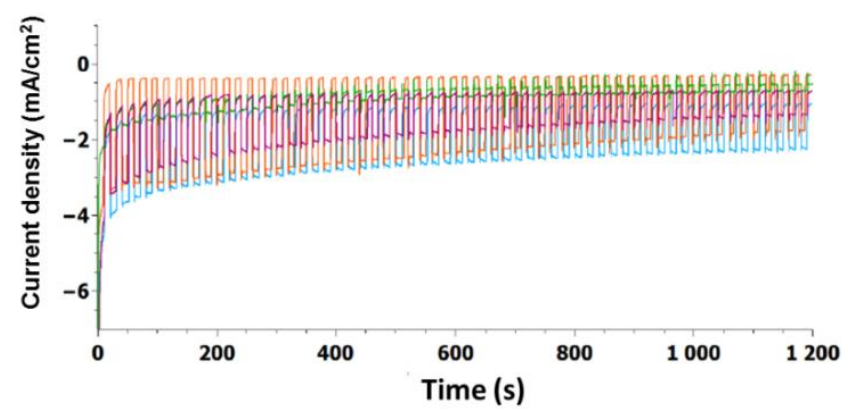

Figure 4. Chronoamperometry measurements at $0 \mathrm{~V}$ vs. RHE and $\mathrm{pH}=6$ for different $\mathrm{Cu} / \mathrm{Cu}_{2} \mathrm{O} / \mathrm{CuO}$ photoelectrodes under chopped visible-light irradiation (3 sun): EA 15-15 (blue); EA 20-20 (orange); EA 25-25 (green) and EA 30-30 (purple).

\section{Synthesis and Characterization of $\mathrm{Cu}$-based photoelectrode- $\mathrm{BaTiO}_{3}$.}

The protection of $\mathrm{Cu} / \mathrm{Cu}_{2} \mathrm{O} / \mathrm{CuO}$ photoelectrodes by $\mathrm{BaTiO}_{3}$ was then investigated in order to achieve stable current. The $\mathrm{BaTiO}_{3}$ perovskite material was selected because of its $n$-type character suitable for fabricating a $p-n$ junction together with its conduction band edge potential slightly positive to the one of $\mathrm{CuO}$ and $\mathrm{Cu}_{2} \mathrm{O}$, still negative to the $\mathrm{H}_{2}$ evolution potential (Figure 1). Furthermore, $\mathrm{BaTiO}_{3}$ is stable in aqueous solution over a large range of $\mathrm{pH} .{ }^{34}$

The procedure to fabricate the $\mathrm{Cu}$-based photoelectrodes protected by $\mathrm{BaTiO}_{3}$ is detailed in the experimental section. Several layers (at least 2) were necessary to cover uniformly the rough surface of the $\mathrm{Cu} / \mathrm{Cu}_{2} \mathrm{O} / \mathrm{CuO}$ photoelectrodes and a final heat-treatment at $600^{\circ} \mathrm{C}$ in the air was applied to crystallize the perovskite film. XRD patterns measured before and after the $\mathrm{BaTiO}_{3}$ sol-gel deposition confirm the presence of the perovskite phase (Figure 5.1). The intensity of the $\mathrm{BaTiO}_{3}$ peaks is low compared to the ones corresponding to $\mathrm{Cu}_{2} \mathrm{O}$ and $\mathrm{CuO}$, indicating that the thickness of the protective layer is low (i.e. 200-300 nm). Note that the $\mathrm{CuO} / \mathrm{Cu}$ ratio is different in electrode without and with $\mathrm{BaTiO}_{3}$ layer. There is more $\mathrm{CuO}$ for electrode with $\mathrm{BaTiO}_{3}$ layer. Probably, it has been formed during the deposition of the perovskite layer, in oxidizing atmosphere at high temperature $\left(600^{\circ} \mathrm{C}\right)$.

The $\mathrm{BaTiO}_{3}$ film was deposited, for the first time, on top of the $\mathrm{Cu} / \mathrm{Cu}_{2} \mathrm{O} / \mathrm{CuO}$ photoelectrodes by the sol-gel method coupled with the dip-coating process.
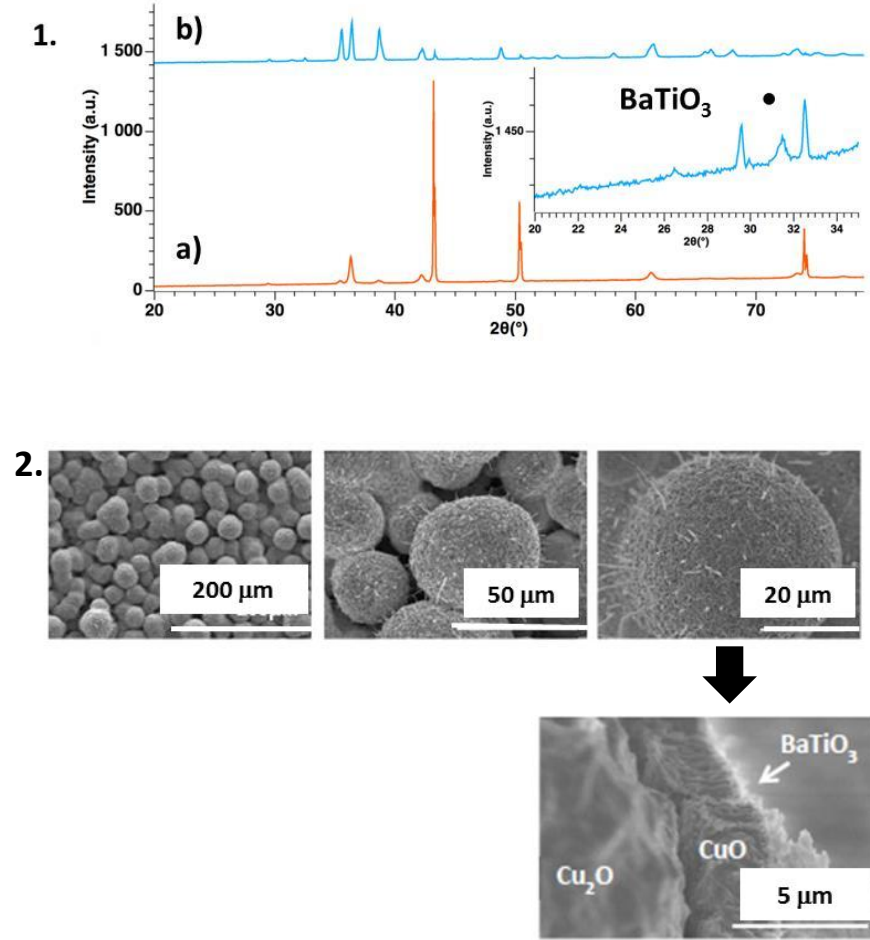

Figure 5. Structural characterization, particle morphology and optical properties of $\mathrm{Cu} / \mathrm{Cu}_{2} \mathrm{O} / \mathrm{CuO} / \mathrm{BaTiO}_{3}$ photoelectrodes. 1) $\mathrm{X}$-rays diffraction patterns of electrodes without (a) and with (b) $\mathrm{BaTiO}_{3}$ protecting layer; the inset is a magnification of trace (b) with the presence of $\mathrm{BaTiO}_{3}$ marked by the black point; 2) SEM images of the $\mathrm{BaTiO}_{3}$-protected electrodes.

This is confirmed by cross-section SEM analyses (see Figure 5.2). The thickness of the $\mathrm{BaTiO}_{3}$ layer was estimated to be 200-300 nm while the $\mathrm{CuO}$ and $\mathrm{Cu}_{2} \mathrm{O}$ layers are 1-2 $\mu \mathrm{m}$ and $15 \mu \mathrm{m}$ thick, respectively. Note that the thickness of the $\mathrm{Cu}_{2} \mathrm{O}$ layer is augmented in comparison with the bare electrode. This is due to the heat treatment in the air at $600^{\circ} \mathrm{C}$ needed for the synthesis of $\mathrm{BaTiO}_{3}$ that partly converts $\mathrm{Cu}$ into $\mathrm{Cu}_{2} \mathrm{O}$. Otherwise, a comparison of the microstructure of the electrode before and after $\mathrm{BaTiO}_{3}$ deposition indicated that the microstructure of the $\mathrm{Cu} / \mathrm{Cu}_{2} \mathrm{O} / \mathrm{CuO}$ photoelectrodes remains unchanged, except for the ratio $\mathrm{Cu} / \mathrm{Cu}_{2} \mathrm{O} / \mathrm{CuO}$ ratio and the presence of the thin layer of $\mathrm{BaTiO}_{3}$ on top of the photoelectrodes. The UV-visible diffuse reflectance spectra (Figure SI.1)) are similar to those observed for $\mathrm{Cu} / \mathrm{Cu}_{2} \mathrm{O} / \mathrm{CuO}$ electrodes. A slight increase of the absorbance was observed in the UV region due to the presence of $\mathrm{BaTiO}_{3}$ exhibiting a band gap of $3.8 \mathrm{eV}$. The TAUC plot indicates a bandgap of $1.1 \mathrm{eV}$ which is in agreement with the values measured previously onto the bare electrodes. EDX analyses indicated a $\mathrm{Ba} / \mathrm{Ti}$ ratio of 1 , confirming the presence and stoichiometry of perovskite $\mathrm{BaTiO}_{3}$.

The photoelectrochemical performances of surface-protected electrodes were evaluated under 3 sun visible--light irradiation and Table 2 summarizes the results. In this Table, the photocurrent values refer to the value measured at $0 \mathrm{~V}$ versus RHE during the linear sweep voltammetry ( $j-V$ plot, Figure 6$)$ under chopped illumination. 
Table 2. Current density measured at $0 \mathrm{~V}$ vs. RHE from I-V curves and $\mathrm{pH}=6$ under 3 sun visible-light irradiation for copper-based photoelectrodes produced with different synthesis conditions.

\begin{tabular}{ccccccc}
\hline \multirow{2}{*}{ Electrode } & \multicolumn{2}{c}{ EA15-15 } & \multicolumn{2}{c}{ EA20-20 $^{2}$} & \multicolumn{2}{c}{ EA30-30 } \\
\cline { 2 - 7 } & - & BaTiO $_{3}$ & - & BaTiO $_{3}$ & - & BaTiO $_{3}$ \\
\hline $\begin{array}{c}\text { Current } \\
\text { density } \\
\left(\mathrm{mA} . \mathrm{cm}^{-2}\right)\end{array}$ & -2.2 & -2.5 & -2.5 & -3.1 & -3.3 & -3.0 \\
\hline
\end{tabular}

Photocurrent values ranging between - 2.5 and $-3.1 \mathrm{~mA} . \mathrm{cm}^{-2}$ at $0 \mathrm{~V}$ vs $\mathrm{RHE}$ at $\mathrm{pH}=6$ are obtained, slightly higher than the ones measured for the bare $\mathrm{Cu} / \mathrm{Cu}_{2} \mathrm{O} / \mathrm{CuO}$ photoelectrodes prepared with the same procedure. Note that for this study the bare electrodes have received a heat-treatment at $600^{\circ} \mathrm{C}$ under air, treatment used when $\mathrm{BaTiO}_{3}$ is deposited ontop of the $\mathrm{Cu} / \mathrm{Cu}_{2} \mathrm{O} / \mathrm{CuO}$ photoelectrodes. As a consequence, the photocurrents are slightly lower than those measured on the previous set of values due to the difference of the $\mathrm{Cu} / \mathrm{Cu}_{2} \mathrm{O} / \mathrm{CuO}$ ratio.

The stability of the photocurrent was then evaluated through chronoamperometric measurements performed at $0 \mathrm{~V}$ versus $\mathrm{RHE}$ under chopped light over $20 \mathrm{~min}$ at $\mathrm{pH}=6$. Figure 7 summarizes the results obtained on bare and $\mathrm{BaTiO}_{3}$-protected electrodes.

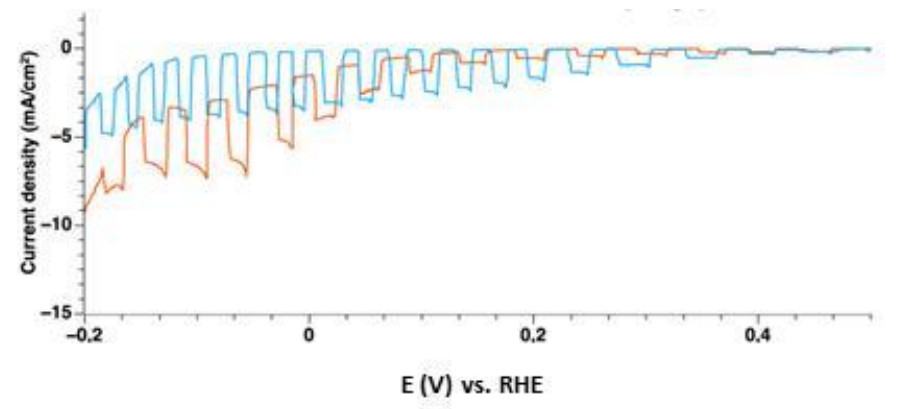

Figure 6. Photo electrochemical response for $\mathrm{BaTiO}_{3}$-protected electrodes. Current-potential characteristics at $\mathrm{pH}=6$, under chopped light illumination (visible light, 3 sun) for $\mathrm{BaTiO}_{3}$-protected (blue) and bare (orange) EA $20-20 \mathrm{Cu} / \mathrm{Cu}_{2} \mathrm{O} / \mathrm{CuO}$ photoelectrodes.

Bare $\mathrm{Cu} / \mathrm{Cu}_{2} \mathrm{O} / \mathrm{CuO}$, although exhibiting a large photocurrent in the first minutes as reported before, ${ }^{34,35}$ unsurprisingly exhibited more than $50 \%$ decrease in current within 20 min. Under the same conditions, the protected $\mathrm{Cu} / \mathrm{Cu}_{2} \mathrm{O} / \mathrm{CuO} / \mathrm{BaTiO}_{3}$ electrodes show higher photocurrent and a decrease of $15 \%$ in photocurrent was observed within the first $3 \mathrm{~min}$. After this initial decrease, the protected photoelectrodes showed a stable photocurrent density (values given in Table 2), indicating complete coverage of the $\mathrm{Cu} / \mathrm{Cu}_{2} \mathrm{O} / \mathrm{CuO}$ photoelectrodes by $\mathrm{BaTiO}_{3}$ with few pinholes. This clearly demonstrates the impact of the $p-n$ junction on the photo-induced charge transfer process as the electrical field at the junction aids to separate hole/electron, limiting thereby recombination.

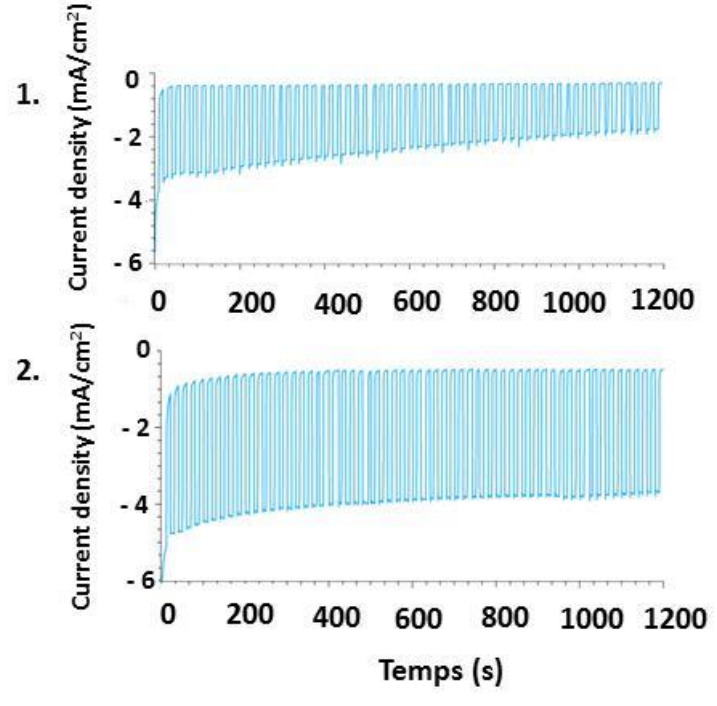

Figure 7. Chronoamperometry measurements at $0 \mathrm{~V}$ vs. RHE and $\mathrm{pH}=6$ for bare (1) and $\mathrm{BaTiO}_{3}$ - protected $\mathrm{Cu} / \mathrm{Cu}_{2} \mathrm{O} / \mathrm{CuO}$ (EA 20-20) photoelectrodes (2) under chopped visible-light irradiation (3 sun).

The production of hydrogen was confirmed by the formation of bubbles continuously evolving from the various photocathodes studied during illumination (Figure SI3). Using gas chromatographic analysis, a faradaic efficiency of $85 \%$ has been measured for the protected electrode after one hour at $0 \mathrm{~V}$ versus RHE to be compared with the lower value of $66 \%$ found for the bare electrode. Such ameliorating effect of the protective layer directly derives from the prevention of copper oxide photocorrosion.

In order to clarify the origin of the high photoactivity of the $\mathrm{Cu} / \mathrm{Cu}_{2} \mathrm{O} / \mathrm{CuO}$ photoelectrodes, electrochemical impedance spectroscopy and Mott-Schottky experiments were performed to investigate the charge transfer rate at the semiconductor/solution interface. Flat band potential was measured by Mott-Schottky experiments for bare electrode and protected electrodes (Figure 8 ). The slope in the low potential region is negative attesting of the $p$-type character of both photoelectrodes. The flat-band potential values are $0.55( \pm 0.03)$ and $0.70( \pm 0.03) \mathrm{V}$ vs RHE for $\mathrm{Cu} / \mathrm{Cu}_{2} \mathrm{O} / \mathrm{CuO}$ and $\mathrm{Cu} / \mathrm{Cu}_{2} \mathrm{O} / \mathrm{CuO} / \mathrm{BaTiO}_{3}$, respectively, in line with the highest onset potential observed for $\mathrm{BaTiO}_{3}$-protected photoelectrode in Figure 6 . Such a behaviour likely results from the formation of a $\mathrm{p}-\mathrm{n} \mathrm{CuO} / \mathrm{BaTiO}_{3}$ junction, increasing band bending and then enhancing the space-charge region, as already observed for $\mathrm{Cu}_{2} \mathrm{O} / \mathrm{ZnS}$ junction. ${ }^{36,}{ }^{37}$ The impedance spectroscopy for bare electrode and protected electrodes under dark and light conditions has been performed to evaluate charge transfer resistance (see Figure SI.2). Nyquist diagrams are shown in Figure SI.2. The semicircle observed at low frequencies corresponds to the charge transfer resistance across the semiconductor/electrolyte interface and the diameter of the semicircle represents the charge transfer resistance, Rct, which was modelled using a Randles equivalent circuit. The results are summarized in Table 3. 


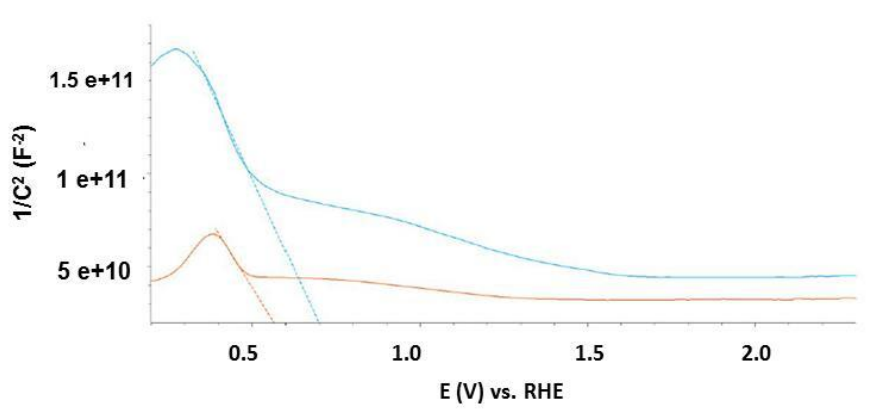

Figure 8. Mott-Schottky diagrams for unprotected (red) and $\mathrm{BaTiO}_{3}$-protected (red) EA $20-20 \mathrm{Cu} / \mathrm{Cu}_{2} \mathrm{O} / \mathrm{CuO}$ electrodes at $\mathrm{pH}=6$.

Table 3. Charge transfer resistances (Rct) determined from impedance spectroscopy for the studied photoelectrodes and EA $20-20 \mathrm{Cu} / \mathrm{Cu}_{2} \mathrm{O} / \mathrm{CuO}$ electrodes protected with $\mathrm{TiO}_{2}$ layer as comparison purpose.

\begin{tabular}{ccc}
\hline \multirow{2}{*}{ Electrode } & \multicolumn{2}{c}{ Rct $(\Omega)$} \\
\cline { 2 - 3 } $\mathrm{Cu} / \mathrm{Cu}_{2} \mathrm{O} / \mathrm{CuO}$ & 1724 & 1183 \\
\cline { 2 - 3 } $\mathrm{Cu} / \mathrm{Cu}_{2} \mathrm{O} / \mathrm{CuO} / \mathrm{BaTiO}_{3}$ & 1745 & 680 \\
$\mathrm{Cu} / \mathrm{Cu}_{2} \mathrm{O} / \mathrm{CuO} / \mathrm{TiO}_{2}$ & 1474 & 914 \\
\hline
\end{tabular}

Rct values decrease upon illumination, indicating that illumination greatly accelerates the charge transfer reaction at the electrode/electrolyte interface due to the photoinduced increase of carrier density. Furthermore, the lowest Rct value was observed for the $\mathrm{BaTiO}_{3}$-protected electrode, in line with the improved photocurrent observed for protected electrodes. As a comparison purpose, the values measured for the best $\mathrm{Cu} / \mathrm{Cu}_{2} \mathrm{O} / \mathrm{CuO} / \mathrm{TiO}_{2}$ photoelectrode described in the introduction is also reported in table 3 . The charge transfer resistance under illumination is improved compare to the bare electrode but the value remains slightly higher than that observed with $\mathrm{BaTiO}_{3}$ protection. Additionally, the faradic efficiency for the various electrodes (Figure $\mathrm{SI} 3$ ) is higher when the electrode is protected by either $\mathrm{BaTiO}_{3}$ or $\mathrm{TiO}_{2}$. Again the best value is found for the electrode protected by $\mathrm{BaTiO}_{3}$. These results confirm that photogenerated electrons may easily cross the electrode/electrolyte interface to react with water to produce $\mathrm{H}_{2}$. This indicates that the main mechanism for $\mathrm{BaTiO}_{3}$-protected electrode is a tandem mechanism where electrons flow to electrolyte and holes flow to substrate. For the $\mathrm{TiO}_{2}$-protected electrode, the photocurrent is lower compared to $\mathrm{BaTiO}_{3}$-protected electrodes in line with a higher Rct value. It is also possible that at the $\mathrm{CuO} / \mathrm{TiO}_{2}$ interface, electrons in the $\mathrm{TiO}_{2}$ conduction band recombine more easily with holes in the $\mathrm{CuO}$ valence band, resulting in a net decrease of the photocurrent. The difference between $\mathrm{TiO}_{2}$ and $\mathrm{BaTiO}_{3}$ may therefore be attributed to the microstructure of the protecting layers (for $\mathrm{BaTiO}_{3}$, the deposition technique and low sintering temperature used produce a film with small particles as well as high ${ }_{40}$ rystallization) as well as fine tuning of band alignment. ${ }^{38,39,}$

\section{Conclusions}

We have successfully employed the electrodeposition/anodization processes coupled with heat-treatment for the synthesis of $\mathrm{Cu} / \mathrm{Cu}_{2} \mathrm{O} / \mathrm{CuO}$ photocathode architectures. These three-component films are available at low cost and through a highly controllable process. They display two major qualities required for photoelectrodes: almost complete absorption of light in the visible region and high specific surface area in contact with the electrolyte and good energy alignment and heterojunction structure avoiding the $\mathrm{e}^{-} / \mathrm{h}^{+}$recombination in the bulk and allowing photogenerated electrons to react with water. The current density measured at $0 \mathrm{~V}$ vs. RHE was as high as - $3.1 \mathrm{~mA} . \mathrm{cm}^{-2}$, although only $60 \%$ of the activity remained after 20 min operation. Such an issue could be overcome through protection by $\mathrm{BaTiO}_{3}$, an n-type semiconductor deposited through the cost-effective sol-gel dip-coating method, which proved more efficient than $\mathrm{TiO}_{2}$ widely used in that prospect. ${ }^{21,41}$ Active $\left(\sim-3.1 \mathrm{~mA} . \mathrm{cm}^{-2}\right)$ and stable photocathodes for $\mathrm{H}_{2}$ evolution with Faradaic efficiency close to $90 \%$ in $\mathrm{pH}=6$ aqueous electrolyte were finally obtained, en route for their integration in photo-electrochemical devices.

\section{Conflicts of interest}

There are no conflicts to declare.

\section{Acknowledgements}

This work was financed by Total Energies Nouvelles and the ANRT and supported by the French National Research Agency (Labex program, ARCANE, ANR-11-LABX-0003-01).

\section{Notes and references}

1. P. V. Kamat, J. Phys. Chem. C, 2007, 111, 2834-2860

2. A. M. Kudo, Y., Chem. Soc. Rev., 2009, 38, 253-278

3. C. O. Morales and R. O. Vargas, Rev Biol Trop, 2014, 62, 1261-1272.

4. J. R. McKone, Lewis, N.S., Gray, H.B., Chem. Mater., 2014, 26, 407-414.

5. Q.-B. Ma, J. P. Hofmann, A. Litke and E. J. M. Hensen, Solar Energy Materials and Solar Cells, 2015, 141, 178-186.

6. C.-C. Hu, J.-N. Nian and H. Teng, Solar Energy Materials and Solar Cells, 2008, 92, 10711076.

7. M. Hara, Kondo, T., Komoda, M., Ikeda, S., Kondo, J. , Domen, K., Hara, M., Shinohara, K., Tanaka, A., Chem. Commun., 1998, 357-358. 
8. J. Luo, Steier, L., Son, M-K., Schreier, M., 28. Mayer, M.T., Grätzel M., Nano Lett., 2016, 16, $1848-1857$

9. A. Y. Oral, Menşur, E., Aslan, M. H. \& Başaran, E., Mater. Chem. Phys. , 2004, 83, 140-144.

10. A. A. Dubale, Su, W.N., Tamirat, A.G., Pan, C-J., Aragaw, B.A., Chen, H-M., Chen C-H., Hwang B-J., J. Mater. Chem., 2014, 2, 18383-18397

11. T. Maruyama, Sol. Energy Mater. \& Solar Cells 1998, 56, 85-92.

12. A. Paracchino, V. Laporte, K. Sivula, M. Gratzel and E. Thimsen, Nat Mater, 2011, 10, 456-461.

13. A. Paracchino, Brauer, J. C., Moser, J.-E., Thimsen, E., Graetzel, M. , J. Phys. Chem. C 2012, 116, 7341-7350.

14. J.-N. Nian, C.-C. $\mathrm{Hu}$ and $\mathrm{H}$. Teng, Int $J$ Hydrogen Energ, 2008, 33, 2897-2903.

15. L. C. Wang, N. R. de Tacconi, C. R. Chenthamarakshan, K. Rajeshwar and M. Tao, Thin Solid Films, 2007, 515, 3090-3095.

16. T. D. Golden, Shumsky , M.G., Zhou , Y., VanderWerf , R.A., Van Leeuwen, R.A., Switzer , J.A., Chem. Mater. , 1996, 8, 24992504

17. C. Kartal, Y. Hanedar, T. Öznülüer and Ü. Demir, Langmuir, 2017, 33, 3960-3967.

18. H. Gerischer, J.Vac.Sci.Technol., 1978, 15, 39. 1422-1428.

19. X. Zhao, Wang, P. Li, B. , Chem. Commun., 2010, 46, 6768

20. Z. Jin, Zhang, X., Li, Y., Li, S. \& Lu, G. , Catal. Commun. , 2007, 8, 1267-1273

21. J. S. Liu, S. J. Laverty, P. Maguire, J. McLaughlin and J. Molloy, J Electrochem Soc, 1994, 141, L38-L40.

22. M. Izakia, Nagaia, M., Maedaa, K., Mohamada,F.B., Motomuraa, K., JSasanoa, J., Shinagawab, T., Wataseb, S., J. Electrochem. Soc. , 2011, 158, D578-D584.

23. K. Nakaoka, Ueyama, J., Ogura, K., J. Electrochem. Soc. , 2004, 151, C661-C665.

24. X. Guo, P. Diao, D. Xu, S. Huang, Y. Yang, T. Jin, Q. Y. Wu, M. Xiang and M. Zhang, Int J Hydrogen Energ, 2014, 39, 7686-7696.

25. G. Ghadimkhani, de Tacconi, N. R. Chanmanee, W., Janaky, C.,Rajeshwar, K. , Chem. Commun. , 2013, 49, 1297-1299

26. Y. Yang, Xu, D., Wu, Q., Diao, P., Scientific Reports, 2016, 6.

27. J. Toupin, PhD-Thesis, 2015, 152.
Under such conditions, the photocurrent is threefold enhanced with regards to solar irradiation.

29. P. A. Korzhavyi, Johansson, B., Swedish Nucl. Fuel Waste Manag. Co, 2011.

30. T. Theivasanthi, Alagar, M., Arxiv Prepr. arXiv1003.6068, 2010.

31. K. Mizuno, Izaki, M., Murase, K., Shinagawa, T., Chigane, M., Inaba, M., Tasaka, A., and Y. Awakura, J. Electrochem. Soc., 2005, 152, C179.

32. A. Paracchino, J. C. Brauer, J. E. Moser, E. Thimsen and M. Graetzel, Journal of Physical Chemistry C, 2012, 116, 7341-7350.

33. L. Yuan, Wang, Y., Mema, R., Zhou, G., Acta Mater. Chem. Phys., 2011, 59, 491-2500.

34. I. E. Castelli, K. S. Thygesen and K. W. Jacobsen, Topics in Catalysis, 2014, 57, 265272.

35. Z. H. Zhang and P. Wang, Journal of Materials Chemistry, 2012, 22, 2456-2464.

36. Z. Zhang, Wang, P. , J. Mater. Chem., 2012, 22, 2456

P. C. Dai, W. Li, J. Xie, Y. M. He, J. Thorne, G. McMahon, J. H. Zhan and D. W. Wang, Angewandte Chemie-International Edition, 2014, 53, 13493-13497.

E. Grabowska, Applied Catalysis B: Environmental 2016, 186, 97-126.

A. M. Paracchino, N.; Hisatomi, T.; Stefik, M.; Tilley, S.D.; Graetzel, M., Energy \& Environmental Science, 2012, 8673-8681.

40. L. S. Azevedo, L.; Dias, P.; Stefik, M.; Sousa, C.T.; Araujo, J.P., Mendes, A., Graetzel, M.; Tilley, S.D., Energy \& Environmental Science, 2014, 7, 4044-4052.

41. D. Bae, Seger, B., Vesborg, P.C., Hansen, O., Chorkendorff, I., Chem. Soc. Rev., 2007, 46, 1933-1954. 